\title{
Can Entrepreneurship Education Reduce Stereotypes Against Women Entrepreneurship?
}

\author{
Esra Sena Türko ${ }^{1}$ \\ ${ }^{1}$ Faculty of Economics and Administrative Sciences, Erzurum Technical University, Erzurum, Turkey \\ Correspondence: Esra Sena Türko, Faculty of Economics and Administrative Sciences, Erzurum Technical \\ University, 25100, Erzurum, Turkey. Tel: 90-442-666-2528 (2105). E-mail: esturko@erzurum.edu.tr
}

Received: May 23, 2016

doi:10.5539/ies.v9n11p53
Accepted: June 26, $2016 \quad$ Online Published: October 26, 2016

URL: http://dx.doi.org/10.5539/ies.v9n11p53

\begin{abstract}
The aim of this study is to investigate whether entrepreneurship trainings can reduce stereotypes against women entrepreneurship. With this aim socio-psychological obstacles to women entrepreneurship in Turkey are examined, and an experimental study is carried out. Entrepreneurship courses were given with a special emphasis on women entrepreneurship and gender issues. To evaluate the out puts of the experimental study, a questionnaire was designed and applied to students. In order to make a comparison, the same questionnaire was applied to students from two other universities, who have taken entrepreneurship courses through the classical method and curricula.

Survey tool includes 21 statements on women entrepreneurship, 5 positive and 16 negative. A non-parametric Mann-Whitney U test was conducted to evaluate the hypothesis that the experimental group would score lower in negative statements and higher in positive statements, on the average, than the non-experimental group. Test results indicate that mean ranks for the two groups differ significantly from each other in 12 items $(\mathrm{p}<.05)$. Experimental group score significantly higher than the non-experimental group in 4 positive and 1 negative statements; and lower than the non-experimental group in 7 negative statements. Compared to non-experimental group, experimental group seems to have higher scoring for awareness and advocacy of women entrepreneurship and lower scoring for socio-psychological obstacles against women entrepreneurship. According to the survey results, it can be concluded that modification of entrepreneurship education curricula will contribute to reduce stereotypes hindering women entrepreneurship.
\end{abstract}

Keywords: entrepreneurship education, female entrepreneurship, gender, obstacle, stereotype, women entrepreneurship, Turkey

\section{Introduction and Purpose of the Study}

Women's less entrepreneurial activity compared to men, is examined from different aspects by various disciplines. Social structure by sociology, gender analysis by psychology, legal regulations, women rights and citizenship by political science, entrepreneurial profiles by business administration and development linkages by economics etc. Reasons why women do not become an entrepreneur, sectors women entrepreneurs choose, problems women entrepreneurs encounter at start-up phase and while managing their businesses constitute the general framework of women entrepreneurship studies.

Obstacles against women entrepreneurship can be evaluated in three phases. Barriers hindering women to become an entrepreneur, problems women entrepreneurs encounter at start-up, and problems women entrepreneurs encounter at managing their business. On the other hand obstacles against women entrepreneurship can be classified according to its source as legal, political, social, economic, socio-psychological etc. Stereotypes, as socio-psychological obstacles, negatively effect women's decisions and success in all phases.

Women entrepreneurship studies have been very popular in the last decades. Stereotype concept is often used in socio-psychological obstacle discussions among gender-based evaluations. Gender stereotypes (Gupta et al., 2009; Gupta et al., 2008), occupational stereotypes (Shinar, 1975; Janssen \& Backes-Gellner, 2016), stereotype threat (Max \& Ballereau, 2013), gender discrimination in entrepreneurship (Ascher, 2012), characteristics of female entrepreneurs (Sexton \& Bowman-Upton, 1990; Lewis, 2006), social, cultural and economic problems of 
women entrepreneurs (Okafor \& Amalu, 2010; Chitsike, 2015; Upadhye, 2012), cross country comparative studies (Minniti \& Naudé, 2010; Gupta et al., 2005; Mueller \& Dato-on, 2013), and regional evaluations (Naser et al., 2009; Parvin et al., 2012; Kabir et al., 2012; Mathew, 2010) are some important topics studied under women entrepreneurship domain within this context.

Problems women entrepreneurs encounter in business life are studied with applied researches, in Turkey (Yalman \& Gündoğdu, 2014; İlter, 2010; Kumkale, 2015; Soysal, 2010a; Eryılmaz, 2014; Özkaya, 2009; Cetindamar et al., 2012). And socio-cultural characteristics are examined especially at national level, with conceptual studies (Morçin, 2013; Soysal, 2010b; Keskin, 2014). Conflict components, women in economic life face -either as an employer or employee- are evaluated in applied studies (Ufuk \& Özgen, 2001a; Özkan, 2011; Simşek \& Uzay, 2009). There are also applied studies investigating characteristics (Takay \& Tüzün, 2015; Erdun, 2011), social capital (Yetim, 2008), personal values (Yirik \& Yıldırım, 2014a, 2014b) and profiles (Ufuk \& Özgen, 2001b; Kutanis, 2006, 2005; Kutanis \& Alpaslan, 2006) of women entrepreneurs. But the socio-psychological obstacles, which keep women away from being an entrepreneur, are not investigated specifically with an applied study in Turkey. These obstacles are examined within gender analysis as a part of this scale together with many other gender issues (Zeyneloğlu \& Terzioğlu, 2011; Dökmen, 2009; Çıtak, 2008). There are studies linking gender analysis with development (Adaçay, 2014) and economics (Serdaroğlu, 2010) as well.

Women's entrepreneurial activity is important in terms of national and local economic development. Barriers against women entrepreneurship indicate the gaps and the defects of the entrepreneurial eco-system. Regional, national and international funded programmes and projects are widely executed to promote women's participation into economic life and reduce and diminish the obstacles against.

Stereotypes may become as restrictive as to extinguish the option of becoming an entrepreneur, for women. Furthermore, stereotypes may harm the performance of women entrepreneurs as they invoke a stereotype-based expectation of poor performance, which is also known as stereotype threat.

The aim of this study is to investigate whether entrepreneurship trainings can reduce stereotypes against women entrepreneurship. With this aim socio-psychological obstacles to women entrepreneurship in Turkey are examined, and an experimental study is carried out. Entrepreneurship courses were given with a special emphasis on women entrepreneurship and gender issues. To evaluate the out puts of the experimental study, a questionnaire was designed and applied to students. In order to make a comparison, the same questionnaire was applied to students from two other universities in the same region, who have taken entrepreneurship courses through the classical method and curricula.

\section{Concepts and Definitions}

\subsection{Stereotypes}

Stereotyping and prejudice are considered to be the products of adaptive processes, which simplify the complexity of world for people, so that they can devote more cognitive resources to other tasks. Stereotypes are defined as specific beliefs about a group, such as descriptions of what members of a particular group look like, how they behave, or their abilities. Stereotypes are cognitive representations of how members of a group are similar to one another and different from members of other groups (Vescio \& Weaver, 2013). The concept was first used in 1922, by Lipmann (Dökmen, 2009). Prejudice is defined as attitudes and feelings, whether positive or negative and whether conscious or non-conscious, that people have about members of other groups (Vescio \& Weaver, 2013). Stereotypes can be socially shared by a group of people or can exist in the mind of only one person. They are automatically activated, oversimplified, overgeneralized, difficult to change, and strongly influence emotions, judgements, and behaviours (Cox et al., 2012; Dökmen, 2009). By stereotyping we infer that a person has a whole range of characteristics and abilities that we assume all members of that group have. Stereotypes lead to social categorization, which is one of the reasons for prejudice attitudes (e.g. "them" and "us"), which leads to in-groups and out-groups (McLeod, 2008).

Theory and early research on prejudice and stereotypes mainly focus on African Americans and racism. In time, models are adopted to other domains e.g. sexism, heterosexism, ageism etc. Stereotypes related to sex and gender, are prevalent and deep rooted in most cultures throughout the world. Women's rights movements in the 20th century, forced laws to be passed against discrimination of women. Prejudice against women became less socially acceptable but could not been eradicated by these changes. Unlike racism, it is still a more socially acceptable prejudice (Vescio \& Weaver, 2013). Fiske and Stevens (1993) segregate gender stereotypes from others and specify as a fragile issue. They suggest that gender stereotypes rely on power difference. 


\subsection{Stereotype Threat}

Stereotype threat refers to being at risk of confirming, as self-characteristic, a negative stereotype about one's group. This term was first used by Steele and Aronson's (1995) experimental study, which reveals that African-American college students performed more poorly on standardized tests than white students when their race was emphasized. And when race was not emphasized, however, black students performed better and equivalently with white students (Steele \& Aronson, 1995).

In time, research in stereotype threat has broadened and shown that the consequences of stereotype threat can lead to self-handicapping strategies and (e.g., women in math) can reduce the degree that individuals value the domain in question. In education, it can lead students to choose not to pursue the domain of study and, limit the range of professions that they can pursue. In the long-term, stereotype threat may contribute to new social inequality issues. Stereotype threat has also been shown to affect stereotyped individuals' performance in a number of domains, such as white men in sports, women in negotiation, homosexual men in providing childcare and women in driving. When one views oneself in terms of a salient group membership (e.g., "I am a woman, women are not expected to be good at math, and this is a difficult math test"), performance can be undermined because of concerns about possibly confirming negative stereotypes about one's group (ReducingStereotypeThreat). According to Steele and Aronson, stereotype threat generates spotlight anxiety, which causes emotional distress and vigilant worry that may undermine performance (Steele \& Aronson, 1995). Even if people do not internalize stereotypes, they may be vulnerable to stereotype threat, or fears of confirming negative stereotypes of their in-group in the eyes of others, can adversely affect performance (McLeod, 2008; Vescio \& Weaver, 2013).

\subsection{Is It Possible to Reduce Stereotypes?}

Social researchers have been investigating intervention methods that may reduce intergroup prejudice and stereotypes and its social and personal adverse consequences. In the 1980's, social cognition revolution brought a hope that attempts to change stereotypes will be concluded with reductions in prejudices; but findings revealed a reverse situation, stereotypical images of groups were resistant to change. In the late 1990's applied studies indicated that the arousal of positive intergroup feelings and friendship ties could effectively reduce intergroup prejudice. Re-categorization and the redefinition of in-groups, adopting the perspective of out-group members were shown to result with arousal of empathy and improved intergroup attitudes. Perspective taking is critical for prejudice reduction interventions and inspires approach tendencies that will bring people of different groups together (Vescio \& Weaver, 2013). There are also applied studies examining methods for reducing automatic stereotype activation by situational attribution training (Stewart, Latu, Kawakami, \& Myers, 2010) and stereotype suppression for effortful egalitarianism (Cralley, 1999).

Cox et al. (2012) makes a distinction between stereotype reduction techniques, as attempt to "fight fire with fire" through the use of automatic, non-intentional methods to reduce automatic, non-intentional stereotyping; and "fight fire with water" through the use of controlled, effortful processing to override and restructure automatic stereotyping in the long-term stereotype change. In the study cognitive behavior therapy is defined as an effective, empirically supported intervention that harnesses effortful processing to override and restructure stereotypes. Furthermore, Cox et al. examines the intervention methods to reduce stereotypes with an integrated perspective together with prejudice and depression. They suggest that some intervention methods developed for depression may be useful against prejudice and stereotypes and some intervention methods developed for prejudice and stereotypes may be useful against depression.

Gist (1995) examines the stereotype change through inconsistency. In her study she defines inconsistency with a literature review, as information that does not appear to fit with the existing stereotype attributes, and states that inconsistency is considered to be crucial for stereotype change. If stereotypes are conceptualized as lists of independent attributes, any attribute not included in the stereotype list, or typically considered to be the opposite of or in conflict with an attribute included in the list, would be considered inconsistent with the stereotype. Stereotype change through inconsistency can be reflected in two ways: central tendency and variability. When a stereotype changes to accommodate inconsistent information, the perceiver might change his/her overall impression of the group's central tendency on a given dimension, or might simply extend the variance expected on that dimension without changing the expected central tendency (Gist, 1995).

\section{Literature Review}

Within the general framework of women entrepreneurship research, there are plenty of studies examining problems women encounter, with a gender-based approach. Their framework have been outlined with "gender, stereotype, prejudice, discrimination, cultural or social problems/obstacles" concepts, and carried out in different 
regions throughout the world. These studies approve the suggestion of the social psychologists that gender stereotypes exist everywhere in the world with similarities and differences stemming from culture (Dökmen, 2009). The stereotype about women's performance in math is a good example to understand this circumstance. There are many applied studies searching methods for reducing stereotype threat for women in math tests (Rosenthal \& Crisp, 2006; Aronson et al., 1999; Pelligrini, 2005; Marsden 2014). But this stereotype is not viable in Turkey at all. On the other hand Gupta et al. (2005) have carried out a comparative field survey examining gender role stereotypes and entrepreneurial intentions; and a similar pattern of gender role typing of entrepreneurship is noted among students from USA, India, Turkey. Despite cultural, geographical, religious and historical differences, "think entrepreneur-think male" phenomenon existed in the sample among three countries. Study results suggest that, as entrepreneurial thinking may partly be universal, and then gender role stereotyping may be the universal dimension of entrepreneurial thinking.

Pressure from family, competitors and community, are great obstacles to women entrepreneurship. It is widely believed that women will encounter this sort of pressure if they decide to become an entrepreneur. But actually is this situation still valid today? Recent field research in Turkey indicates that socio-psychological obstacles against women entrepreneurship do not have supporters as much as they were thought. For example the stereotype, that when woman becomes an entrepreneur she will encounter problems with men other than family members and she cannot handle it by herself, is in fact a fright exists in potential women entrepreneurs and their families. But surveys reveal that the present situation does not comprise a threat to cause a fright of this kind. Besides male entrepreneurs may encounter similar problems with their competitors either. On the other hand conceptual studies describe more pessimistic view framework for Turkish women entrepreneurs and the obstacles. Considering this contrariety some recent important conceptual and applied studies about women entrepreneurs in Turkey are reviewed below.

Uluköy and Bayraktaroğlu (2014) have carried out a field research in Adıyaman and Balıkesir, two provinces with different cultural backgrounds, to reveal the oppression women entrepreneurs encounter in Turkey. They state that the sources of oppression are family, male competitors, relatives and community. These pressure types sometimes may turn into a physical attempt such as violence, abuse, threat, intimidation, humiliation, and exclusion. According to the study results, women entrepreneurs had not encountered much oppression at start-up or following phases and there is not any significant difference between demographic features of female entrepreneurs and their entrepreneurial characteristics, oppressions and obstacles they encounter. Among the sample, $5 \%$ were harassed and threatened by male entrepreneurs, $16 \%$ were subject to discouragement, $9,5 \%$ were insulted, $14,3 \%$ were subject to isolation and none of them was subject to violence. And finally the percentage of female entrepreneurs being hindered by either their own families or male entrepreneurs is $24 \%$. Uluköy and Bayraktaroğlu indicate that in a patriarchal society this ratio is considered to be low. Nevertheless they state that despite government policies protecting women and promoting women entrepreneurship programmes, women entrepreneurship is still being hindered.

A very common stereotype is that women entrepreneurs act different in some cases, and so they have different behaviour patterns than men. And these behaviour patterns indicate characteristics that a successful entrepreneur should not possess. The most important stereotypes of this kind are about risk taking and self-confidence.

There are limited researches investigating difference in entrepreneurial characteristics on gender bases in Turkey. Uluköy and Demireli (2014) have found that there is significant difference on self-confidence, tolerance to uncertainty, independence, evaluating opportunities, innovation, leadership and internal control according to gender. On the other hand, according to the study, there is no significant difference on risk taking, vision, success motivation and communication skills between male and female entrepreneurs.

Another very common stereotype is that women are emotional and this characteristic makes women weak in work-life. Applied field studies do not support this statement either. Güleç (2011) investigates the profile of women entrepreneurs in Karaman province and also examines the problems women entrepreneurs encounter. According to the survey results women rarely state being emotional as a problem in work-life. Güleç argues that obstacles women entrepreneurs encounter in work-life mainly stem from defects in economic, social and cultural structure.

Religions are strong factors shaping societies. And perceived religious beliefs/values may vary across countries or even within a country and region. Diversity of religious perceptions, effect women entrepreneurship differently, positive or negative. Extremist interpretations of religions generally have negative approach to women entrepreneurship. These extremist interpretations may exist everywhere in every religion. Among these perceived religious beliefs/values, major stereotypes in Turkey will be summarized in this study. Some people 
claim that women should stay away from work-life according to their religious values, in order to provide stronger family fundamentals and raise up more qualified generations. On the other side according to this view, women are vulnerable because of their weak physical nature, and may fail to overcome external threats and abuses, by themselves. Moreover, women's too much occupation out of home may be turned into a moral conflict by extremist approaches. These issues are studied within gender analysis framework under psychology domain, and there is no study investigating the relation between perceived religious beliefs/values and women entrepreneurship in Turkey.

There are plenty of publications on Islam's approach to various economic activities, in Turkey. Among these publications entrepreneurship is not studied much. In his conceptual study Eren (2012) states that this issue is neglected; and Islam has some fundamentals, which promotes and even entails entrepreneurship. But a gender-based assessment does not exist in Eren's study; women's participation into economic life or women's entrepreneurship is not mentioned.

Roles in family, imposed by the society and child and elder care responsibilities are important obstacles against women's entrepreneurship. It is a very strong stereotype that when woman participates into working-life, she will neglect her duties at home and in this case her family-life responsibilities are more important. Batı and İnel (2015) have carried out a field research on work-family conflict, interface and balance in Yalova province. Study consists of interviews with 15 women entrepreneurs and investigates entrepreneurs' risk taking, innovation and self-confidence features as well. Batı and İnel state that, women entrepreneurs cannot abandon their responsibilities in family life, independent from their success condition in work-life. In order to increase productivity and avoid conflicts both at home and at work, women adopt solution strategies, as Shelton (2006) offers: role elimination, role reduction, role sharing and postponing role conflict (Batı \& İnel, 2015).

Morçin (2013) makes a conceptual evaluation and defines the Turkish women entrepreneurs' profile with reference to Hofstede's cultural dimensions. She offers Turkish women entrepreneurs to have the following features and behaviour patterns: Turkish women entrepreneur is raised up in a collective culture, therefore she possess a lower grade of entrepreneurship. Turkish society has high grade of uncertainty avoidance, so Turkish women entrepreneur has low grade of risk taking and her attempts are less supported by close environment. As power distance is high in Turkish society, inequalities are more likely to be responded with tolerance, so Turkish women entrepreneur has to struggle with this point of view either. Turkish women entrepreneur is raised up in a short-term normative oriented society therefore she is hasty and impatient and more tended to make mistakes. Turkish society is more feminine but roles allocated by the society hinder this advantage for the women entrepreneur.

\section{Method}

Compatible with the purpose of the study, it is decided to carry out the Entrepreneurship and Economies of Knowledge and Innovation classes with a special emphasis on women entrepreneurship, at Erzurum Technical University Faculty of Economic and Administrative Sciences (FEAS) in spring semester 2015. Students -in two groups- were given (3 hours a week for 14 weeks) 42 hours of training and were taught to prepare Osterwalder's business model canvas. During the semester several issues are examined with a special emphasis on women entrepreneurship and some traditions and social problems are criticised linking gender issues. (Female homicides, child brides, honour killings etc.)

Two workshops were (three-hour each) organized to determine the scale to be used in the survey tool in March 2015. First, a discussion was made in the classroom on characteristics of successful entrepreneurs. Through a critical point of view, these characteristics were assessed as conditional and stereotypical; and exceptional real-life examples were given by the trainer. Then students were requested to form groups of 5-6 persons and asked whether female entrepreneurs can be as successful as male entrepreneurs. Groups were requested to write down the success/failure factors they agree on, and present their group opinion in the class. With this exercise, it was aimed to detect the stereotypes. Students comfortably expressed their opinions within their groups; then presented the ones in the class, which they believe to be accurate. Discussions were allowed during presentations. This issue had come onto the students' agenda. All the negative statements purposed by the group representatives were assessed as an exceptional case and disproved with opposite examples.

Later in the workshop, groups were asked to discuss the obstacles against women entrepreneurship and problems women entrepreneurs encounter. Again, groups were requested to write down the factors they agree on, and present their group opinion in the class. Discussions were made during group presentations.

Students were told to get prepared for a question about "the relationship between women entrepreneurship and economic development" in the mid-term exam, and worldwide/country specific data use was obligatory to 
support their argument. Students had to make detailed research about the subject. The following questions were asked in the mid-term exam: Is it important to support women entrepreneurship in an economy, which has growth targets? How does women entrepreneurship contribute to economic development level? Discuss the present situation in Turkey using women entrepreneurship data from developing and developed countries. What are the obstacles against women entrepreneurship in Turkey, please discuss.

At the end of the semester the questionnaire is designed by the trainer and delivered to 101 students, after the submission of business models in May 2015. In order to make a comparison, the same questionnaire was applied to 53 students from Atatürk University FEAS and 60 students from Erzincan University FEAS, on the last day of the Entrepreneurship classes in May 2015.

The items used in the questionnaire are derived from the students' statements expressed in the workshops. The trainer has collected, grouped and eliminated the items to get a thorough survey tool. All items are presented in statements and respondents were requested to answer anonymously on a five-point Likert scale to what extent they agree with the statement. (Strongly disagree, disagree, neither agree nor disagree, agree and strongly agree) Students were requested to fill the forms by themselves in the classroom.

\section{Statistical Analysis of the Survey}

The main research question of this study is whether it is possible to reduce stereotypes against women entrepreneurship by teaching entrepreneurship with a special emphasis on women entrepreneurship and gender issues.

The sample consists of 214 students of three universities in two provinces: Erzurum Technical University (ETU) and Atatürk University (AU) in Erzurum, and Erzincan University (EU) in Erzincan. The sample is divided into two groups as, the experimental group, which has taken the entrepreneurship class with a special emphasis on women entrepreneurship; and the non-experimental group, which has not taken the entrepreneurship class with a special emphasis on women entrepreneurship. Number of students in the first group (experimental group from ETU) is 101, and in the second group (non-experimental group from AU and EU) is 113. The sample consists of 127 female (59\%) and 87 male (41\%) students in total.

\subsection{Survey Items-Negative Statements}

1. As women are emotional they can't handle the stress of work as well as men.

2. Women cannot manage business planning with complex manufacturing processes as well as men.

3. Women's primary responsibility is to care for family and children; work comes later.

4. If women have economic independence their commitment to home will reduce.

5. Because of women's too much occupation in work life, men cannot find jobs and make a living for their families.

6. When women start-up business, their employees would not respect their authority and listen to reason.

7. When women start-up business, they will have to get in touch with male strangers. I don't like it.

10. Government's resource allocation to support women entrepreneurs is waste of resources. If those resources were allocated to male entrepreneurs, they would be used more efficiently.

11. It is easy to cheat women, they are easily get fraud by suppliers and customers.

12. Women get less risk when they start-up business.

13. Woman's place is her home, she should not work.

14. Women should only work or start-up a business if men from the family are in.

15. Starting-up a business alone will cause a threat for woman's security. She can't handle if someone wants to harm her.

19. I don't mind what the other women do, I don't want my wife, sister or mother to start up a business.

20. According to our religion values women should not start up their own business and work.

21 . Women can become entrepreneurs but they can't be as successful as men.

\subsection{Survey Items-Positive Statements}

8. If my mother wants to start up a business, I'd support her about everything.

9. If I get married in the future and my wife/husband wants to start up a business, I'd support her/him about 
everything.

16. As women's education levels rise, their tendency to become an entrepreneur rises.

17. Increase in the number of women entrepreneurs is important in terms of our economic development.

18. Women's empathy ability is higher than men, they become more successful in customer relations.

Survey tool includes 21 statements on women entrepreneurship, 5 positive and 16 negative. Cronbach's alpha, as a measure for internal consistency and reliability (Sijtsma, 2009), for 21 items is calculated as .823. A non-parametric Mann-Whitney U test was conducted to evaluate the hypothesis that the experimental group would score lower in negative statements and higher in positive statements, on the average, than the non-experimental group. Test results indicate that mean ranks for the two groups differ significantly from each other in 12 items $(\mathrm{p}<.05)$. Test statistics and ranks are presented in the table below. Among these 12 items, 4 of them consist positive and 8 of them consist negative statements. When the ranks of these items are evaluated, experimental group score significantly higher than the non-experimental group in 4 positive and 1 negative statements. On the other hand, non-experimental group score significantly higher than the non-experimental group (experimental group score significantly lower than the non-experimental group) in 7 negative statements.

Compared to non-experimental group, experimental group seems to have higher scoring for awareness and advocacy of women entrepreneurship and lower scoring for socio-psychological obstacles against women entrepreneurship.

Table 1. Ranks and test statistics

\begin{tabular}{|c|c|c|c|c|c|c|c|c|}
\hline & & $\mathbf{N}$ & $\begin{array}{l}\text { Mean } \\
\text { Rank }\end{array}$ & $\begin{array}{l}\text { Sum of } \\
\text { Ranks }\end{array}$ & $\begin{array}{c}\text { Mann-Whit } \\
\text { ney } U\end{array}$ & Wilcoxon W & $\mathbf{Z}$ & $\begin{array}{c}p \\
\text { value }\end{array}$ \\
\hline $\begin{array}{l}\text { 5. Because of women's too much } \\
\text { occupation in work life, men } \\
\text { cannot find jobs and make a } \\
\text { living for their families. (-) }\end{array}$ & 2 & 101 & 97.53 & $\begin{array}{r}9850.50 \\
13154.50\end{array}$ & 4699.500 & 9850.500 & -2.355 & .019 \\
\hline $\begin{array}{l}\text { 7. When women start-up } \\
\text { business, they will have to get in } \\
\text { touch with male strangers. I don't } \\
\text { like it. (-) }\end{array}$ & 1 & 101 & 114.75 & 12852.00 & 4788.000 & 9939.000 & -1.987 & .047 \\
\hline $\begin{array}{l}\text { 8. If my mother wants to start up a } \\
\text { business, I'd support her about } \\
\text { everything. }(+)\end{array}$ & 2 & 113 & 116.63 & $\begin{array}{l}11779.50 \\
11225.50\end{array}$ & 4784.500 & 11225.500 & -2.178 & .029 \\
\hline $\begin{array}{l}\text { 10. Government's resource } \\
\text { allocation to support women } \\
\text { entrepreneurs is waste of } \\
\text { resources. If those resources were } \\
\text { allocated to male entrepreneurs, } \\
\text { they would be used more } \\
\text { efficiently. (-) }\end{array}$ & 1 & 113 & 119.30 & 13481.00 & 4373.000 & 9524.000 & -3.180 & .001 \\
\hline $\begin{array}{l}\text { 13. Woman's place is her home, } \\
\text { she should not work. (-) }\end{array}$ & $\begin{array}{l}1 \\
2\end{array}$ & $\begin{array}{l}101 \\
113\end{array}$ & $\begin{array}{c}98.11 \\
\mathbf{1 1 5 . 8 9}\end{array}$ & $\begin{array}{r}9909.50 \\
13095.50\end{array}$ & 4758.500 & 9909.500 & -2.248 & .025 \\
\hline $\begin{array}{l}\text { 14. Women should only work or } \\
\text { start-up a business if men from } \\
\text { the family are in. (-) }\end{array}$ & 1 & 113 & $\begin{array}{r}97.26 \\
\mathbf{1 1 6 . 6 5}\end{array}$ & $\begin{array}{l}9823.50 \\
13181.50\end{array}$ & 4672.500 & 9823.500 & -2.387 & .017 \\
\hline $\begin{array}{l}\text { 15. Starting-up a business alone } \\
\text { will cause a threat for woman's } \\
\text { security. She can't handle if } \\
\text { someone wants to harm her. (-) }\end{array}$ & 2 & 113 & 116.13 & 11275.50 & 4834.500 & 11275.500 & -1.979 & .048 \\
\hline 16. As women's education levels & 1 & 101 & 125.66 & 12691.50 & 3872.500 & 10313.500 & -4.302 & .000 \\
\hline
\end{tabular}




\begin{tabular}{|c|c|c|c|c|c|c|c|c|}
\hline $\begin{array}{l}\text { rise, their tendency to become an } \\
\text { entrepreneur rises. }(+)\end{array}$ & 2 & 113 & 91.27 & 10313.50 & & & & \\
\hline $\begin{array}{l}\text { 17. Increase in the number of } \\
\text { women entrepreneurs is } \\
\text { important in terms of our } \\
\text { economic development. }(+)\end{array}$ & 1 & 101 & 120.41 & 12161.50 & 4402.500 & 10843.500 & -3.058 & .002 \\
\hline $\begin{array}{l}\text { 18. Women's empathy ability is } \\
\text { higher than men, they become } \\
\text { more successful in customer } \\
\text { relations. }(+)\end{array}$ & 1 & 101 & 119.06 & 12025.00 & 4539.000 & 10980.000 & -2.722 & .006 \\
\hline $\begin{array}{l}\text { 19. I don't mind what the other } \\
\text { women do, I don't want my wife, } \\
\text { sister or mother to start up a } \\
\text { business. (-) }\end{array}$ & 1 & 101 & 117.89 & 9683.00 & 4532.000 & 9683.000 & -2.745 & .006 \\
\hline $\begin{array}{l}\text { 21. Women can become } \\
\text { entrepreneurs but they can't be as } \\
\text { successful as men. (-) }\end{array}$ & 2 & 113 & $\begin{array}{r}98.29 \\
\mathbf{1 1 5 . 7 3}\end{array}$ & $\begin{array}{l}9927.00 \\
13078.00\end{array}$ & 4776.000 & 9927.000 & -2.147 & .032 \\
\hline
\end{tabular}

\section{Conclusion and Discussion}

Survey results indicate that there is statistically significant difference between the experimental group and the non-experimental group. Experimental group has significantly higher scoring in 4 positive and 1 negative statements. On the other hand non-experimental group has significantly higher scoring (experimental group has significantly lower scoring) all negative in 7 statements. Compared to non-experimental group, experimental group seems to have higher scoring for awareness and advocacy of women entrepreneurship and lower scoring for socio-psychological obstacles against women entrepreneurship. When carried out with a special emphasis on women entrepreneurship and gender issues, entrepreneurship education may contribute to reduce stereotypes against women entrepreneurship.

According to the survey results, it can be concluded that modification of entrepreneurship education curricula will contribute to reduce stereotypes hindering women entrepreneurship. With this aspect, the study proposes revision and modification of entrepreneurship education curricula in training programmes.

\subsection{The Items Two Groups Do Not Significantly Score Different (Items: 1, 2, 3, 4, 6, 9, 11, 12, 20)}

Two groups do not significantly score different in 1 positive and 8 negative statements. It can be concluded that experimental study has failed to change attitudes on these items. But when the means of these questions are assessed, this situation cannot be defined as a failure. Two groups similarly have low scores in negative statements and high scores in one positive statement. Therefore experimental study has not changed two groups' attitudes, but their attitudes are similarly positive. Negative statements in this group can be classified in two groups: stereotypes representing strong patriarchal stereotypes (women's primary responsibility is to care for family and children $M=2.53, S D=1.430$; women's economic independence will reduce their commitment to home $M=2.40, S D=1.359$; according to our religion values women should not start up their own business and work $M=2.47, S D=1.373$ ) and stereotypes about women in business life (women are emotional they can't handle the stress of work $M=2.89, S D=1.412$; women cannot manage business planning with complex manufacturing processes $M=2.41, S D=1.282$; employees would not respect women entrepreneurs' authority $M=2.07, S D=1.128$; women get less risk $M=2.92, S D=1.246$; women are easily cheated and get fraud by suppliers and customers $M=2.15, S D=1.222$ ). And both groups strongly express support to spouse to start-up a business if they get married in the future $(M=4.05, S D=1.198)$.

\subsection{The Items Experimental Group Score Significantly Higher (Items 8, 15, 16, 17, 18)}

Experimental group has significantly higher scores than the non-experimental group, in 4 positive items (if my mother wants to start up a business, I'd support her; as women's education levels rise, their tendency to become an entrepreneur rises; increase in the number of women entrepreneurs is important in terms of our economic development; women's empathy ability is higher than men, they become more successful in customer relations).

Experimental group has only one significantly higher scoring than the non-experimental group, in one negative statement (starting-up a business alone will cause a threat for woman's security; she can't handle if someone 
wants to harm her). Actually, this statement is directly related to the perception that women are weak. According to this view, women are vulnerable because of their weak physical nature, and may fail to overcome external threats and abuses, by themselves. As mentioned in the literature review, Uluköy and Bayraktaroğlu (2014) have carried out a field research to reveal the oppression women entrepreneurs encounter in Turkey. Among the sample, $5 \%$ were harassed and threatened by male entrepreneurs, $16 \%$ were subject to discouragement, $9,5 \%$ were insulted, $14,3 \%$ were subject to isolation and none of them was subject to violence. And finally the percentage of female entrepreneurs being hindered by either their own families or male entrepreneurs is $24 \%$. Experimental study indicates the persistence of this stereotype. Special curricula modification for this stereotype is proposed for further experimental studies.

\subsection{The Items Experimental Group Score Significantly Lower (Non-Experimental Group Score Significantly Higher) (Items 5, 7, 10, 13, 14, 19, 21)}

These items consist 7 negative statements, which can be assessed as representing mostly patriarchal stereotypes (because of women's too much occupation in work life, men cannot find jobs; women entrepreneurs will have to get in touch with male strangers; government's resource allocation to support women entrepreneurs is waste of resources; woman's place is her home, she should not work; women should only work or start-up a business if men from the family are in; I don't want my wife, sister or mother to start up a business; women entrepreneurs cannot be as successful as men). As a result of this experimental study, these stereotypes are reduced.

Survey results clearly reveal that rising advocacy and awareness about women entrepreneurship through entrepreneurship education and curricula modification is applicable. Besides, survey results indicate that stereotype reduction is possible through education. Curricula modification, specific to stronger stereotypes, will bring further improvement.

In the last decade entrepreneurship trainings became very prevalent in Turkey. Trainings are usually carried out by institutions, which have contracted Small and Medium Enterprises Development Organization (SMEDO) to be eligible to give certificate. As the certificate given to the participants at the end of these trainings is a precondition for applying for SMEDO new entrepreneur grant award, great number of trainings is carried out across the country. To get this certificate, therefore the grant award, is the major motivation of the participants with various demographic characteristics. If SMEDO contracts obligatorily consist curricula covering women entrepreneurship and gender issues patterns, then entrepreneurship trainings will contribute to reduce and diminish the stereotypes, which hinder women entrepreneurship.

This study aims to examine the obstacles against women entrepreneurship in Turkey, as well. With this aim, recent important conceptual and applied studies about women entrepreneurs in Turkey are reviewed. Recent field research in Turkey, indicate that women entrepreneurs do not encounter obstacles as much as it is thought. But these obstacles are like ghosts for women and their families, who has not become an entrepreneur and experience this process yet. Further field research to be made on this issue will reveal that these socio-psychological obstacles are unsubstantial. Carrying out more studies, sharing the research results with the public, and promoting the results in women entrepreneurship programmes will contribute to reduce and diminish this kind of obstacles.

Conceptual studies on Turkish women entrepreneurs' profiles describe a rather pessimistic view. They mostly examine the issue at national level and refer to patriarchal society, determined society roles, low access to education and family pressure. But Turkey is a big country with a population over seventy million and a very rich cultural diversity. And there are great regional socio-economic disparities across regions. Therefore similarities in qualifications and behaviour patterns of women entrepreneurs and obstacles they encounter can be seen in various geographical regions; but at the same time very great differences may exist either. This domain may be discussed more efficiently on local or regional economic development basis.

It is obvious that national policy instruments and support programmes applied for empowerment of women are successful. The increase in women's access to and participation in education, and the decrease in rural-urban population ratio are surely effective in this improvement. But preparing regional profiles, and designing new support mechanisms according to these profiles will bring further success. In each province, universities are established in the last decade, it is a great opportunity. Within this context universities can carry out studies investigating regional profiles in detail and may suggest policy recommendations coherent with regional facts.

\section{References}

Adaçay, F. R. (2014). Toplumsal cinsiyet ve kalkınma. Bursa, Turkey: Ekin Basım Yayın Dağıtım.

Aronson, J., Lustina, M. J., Good, C., Keough, K., Steele, C. M., \& Brown, J. (1999). When White men can’t do 
math: Necessary and sufficient factors in stereotype threat. Journal of Experimental Social Psychology, 35(1), 29-46. http://dx.doi.org/10.1006/jesp.1998.1371

Ascher, J. (2012). Female entrepreneurship - an appropriate response to gender discrimination. Journal of Entrepreneurship, Management and Innovation, 8(4), 97-114.

Batı, G. B., \& İnel, M. N. (2015). Conflict level and investment preferences of women entrepreneurs: Yalova city research. Marmara Üniversitesi Öneri Dergisi, 11(44), 101-119. http://dx.doi.org/10.14783/od.v11i44.5000080006

Cetindamar D., Gupta, V. K., Karadeniz, E. E., \& Egrican, N. (2012). What the numbers tell: the impact of human, family and financial capital on women and men's entry into entrepreneurship in Turkey. $\begin{array}{llll}\text { Entrepreneurship } \quad \& \quad \text { Regional 24(1-2), } & \text { 29-51. }\end{array}$ http://dx.doi.org/10.1080/08985626.2012.637348

Chitsike, C. (2000). Culture as a barrier to rural women's entrepreneurship: experience from Zimbabwe. Gender \& Development, 8(1), 71-77. http://dx.doi.org/10.1080/741923408

Çıtak, A. (2008). Attitude towards woman's working: A comparison according to sex, gender role and socioeconomic status (Unpublished master's thesis). Ankara University Gradute School of Social Sciences, Ankara, Turkey.

Cox, W. T. L., Abramson, L. Y., Devine, P. G., \& Hollon, S. D. (2012). Stereotypes, prejudice, and depression: the integrated perspective. Perspectives on Psychological Science, 7(5), 427-449. http://dx.doi.org/10.1177/1745691612455204

Cralley, E. L. (1999). Effortful egalitarianism: stereotype suppression requires both motivation and cognitive resources (Unpublished doctoral dissertation). Graduate School of Tulane University, Department of Psychology, USA. Available from ProQuest Dissertation \& Theses.

Dökmen, Z. Y. (2009). Toplumsal Cinsiyet (6th ed.). İstanbul, Turkey: Remzi Kitabevi.

Erdun, S. (2011). A study on the risk taking propensity and self confidence of women entrepreneurs: Example of Zonguldak (Unpublished master's thesis). Zonguldak Karaelmas University Graduate School of Social Sciences, Zonguldak, Turkey.

Eren, İ. (2012). Entrepreneurship and religion: An evaluation about Islam's perspective on entrepreneurship with Islam's main sources. Journal of Entrepreneurship and Development, 7(1), 49-68.

Eryılmaz, N. Ş. (2014). Türkiye'de kadın girişimcilerin çalışma hayatında karşılaştıkları sorunlar: Kahramanmaraş örneği (Unpublished master's thesis). Yalova University Gradute School of Social Sciences.

Fiske, S. T., \& Stevens, L. E. (1993). What's so special about sex? Gender stereotyping and discrimination. In S. Oskamp, \& M. Costanzo (Eds.), Gender Issues In Contemporary Society (pp. 173-196). Newbury Park, CA: Sage.

Gist, P. L. (1995). Reexamining stereotype content: The importance of explanatory frameworks for stereotype structure, maintenance, and change (Unpublished doctoral dissertation). University of Michigan, Department of Psychology, Michigan, USA. Available from ProQuest Dissertation \& Theses.

Güleç, S. (2011). Women entrepreneurship-Case of Karaman (Unpublished master's thesis). Karamanoğlu Mehmetbey University Gradute School of Social Sciences, Karaman, Turkey.

Gupta, V. K., Turban, D. B., \& Bhawe, N. M. (2008). The effect of gender stereotype activation on entrepreneurial intentions. Journal of Applied Psychology, 93(5), 1053-1061. http://dx.doi.org/10.1037/0021-9010.93.5.1053

Gupta, V. K., Turban, D. B., Wasti, S. A., \& Sikdar, A. (2005). Entrepreneurship and stereotypes: are entrepreneurs from Mars or from Venus? Academy of Management Proceedings, $\mathrm{C} 1$. http://dx.doi.org/10.5465/AMBPP.2005.18778633

Gupta, V. K., Turban, D. B., Wasti, S. A. \& Sikdar, A. (2009). The role of gender stereotypes in perceptions of entrepreneurs and intentions to become an entrepreneur. Entrepreneurship Theory and Practice, 33(2), 397-417. http://dx.doi.org/10.1111/j.1540-6520.2009.00296.x

İlter, B. (2010). Girişimcilik sürecinde kadın girişimcilerin karşılaşstlkları sorunların analizi: Kagider örneği. Ankara, Turkey: Adalet Yayınevi. 
Janssen, S., \& Backes-Gellner, U. (2016). Occupational stereotypes and gender-specific job satisfaction. Industrial Relations, 55(1), 71-91. http://dx.doi.org/10.1111/irel.12126

Kabir, M. S., Hou, X., Akther, R., Wang, J., \& Wang, L. (2012). Impact of small entrepreneurship on sustainable livelihood assets of rural poor women in Bangladesh. International Journal of Economics and Finance, 4(3), 265-280. http://dx.doi.org/10.5539/ijef.v4n3p265

Keskin, S. (2014). Status of women entrepreneurs in Turkey. Journal of Entrepreneurship and Development, 9(1), 71-94.

Kumkale, İ. (2015). Kadın girişimciliğinin stratejik liderlik yetkinlikleri açısından incelenmesi ve bir araştırma. Bursa, Turkey: Ekin Basım Yayın Dağıtım.

Kutanis R. Ö., \& Alpaslan, S. (2006). Girişimci ve yönetici kadınların profili farklı mıdır? Afyon Kocatepe Üniversitesi IIIBF Dergisi, 8(2), 139-153.

Kutanis, R. Ö. (2005). Perception differences of female and male entrepreneurs: A case study of Sakarya. Presented to the III. Uluslararası Türk Dünyası Sosyal Bilimler Kongresi, June 5-9, Jalal-Abad, Kyrgyzstan.

Kutanis, R. Ö. (2006). Girişsimci kadınlar. İstanbul, Turkey: Değişim Yayınları.

Latu, I. M. (2010). Reducing automatic stereotype activation: Mechanisms and moderators of situational attribution training (Unpublished doctoral dissertation). Georgia State University, College of Arts and Sciences, Department of Psychology, Georgia, USA. Available from ProQuest Dissertation \& Theses.

Lewis, P. (2006). The quest for invisibility: Female entrepreneurs and the masculine norm of entrepreneurship. Gender, Work and Organization, 13(5), 453-469. http://dx.doi.org/10.1111/j.1468-0432.2006.00317.x

Marsden, A. J. (2014). On the construct validity of stereotype threat measures: some possible boundary conditions (Unpublished doctoral dissertation). University of Missouri, St. Louis, USA. Available from ProQuest Dissertation \& Theses.

Mathew, V. (2010). Women entrepreneurship in Middle East: Understanding barriers and use of ICT for entrepreneurship development. International Entrepreneurship and Management Journal, 6(2), 163-181. http://dx.doi.org/10.1007/s11365-010-0144-1

Max, S., \& Ballereau, V. (2013). Theorizing about gender and entrepreneurship: bridging the gap with social psychology. International Journal of Gender and Entrepreneurship, 5(1), 97-110. http://dx.doi.org/10.1108/17566261311305238

McLeod, S. A. (2008). Stereotypes. Retrieved April 20, 2016, from http://www.simplypsychology.org/katz-braly.html

Minniti, M., \& Naudé, W. (2010). What do we know about the patterns and determinants of female entrepreneurship across countries? European Journal of Development Research, 22(3), 277-293. http://dx.doi.org/10.1057/ejdr.2010.17

Morçin, S. (2013). Woman entrepreneurship in Turkish culture: A conceptual evaluation. Journal of Entrepreneurship and Development, 8(2), 167-190.

Mueller, S. L., \& Dato-on, M. C. (2013). A cross cultural study of gender-role orientation and entrepreneurial self-efficacy. International Entrepreneurship and Management Journal, 9, 1-20. http://dx.doi.org/10.1007/s11365-011-0187-y

Naser, K., Mohammed, W. R., \& Nuseibeh, R. (2009). Factors that affect women entrepreneurs: evidence from an emerging economy. International Journal of Organizational Analysis, 17, 225-247. http://dx.doi.org/10.1108/19348830910974932

Okafor, C., \& Amalu, R. (2010). Entrepreneurial motivations as determinants of women entrepreneurship challenges. Petroleum-Gas University of Ploiesti Bulletin, 62(2), 67-77.

Özkan, B. (2011). Kadın girişimciler: Girişimciliğin iş yaşamı-aile yaşamı dengesi üzerindeki etkisinin incelenmesine yönelik bir uygulama (Unpublished master's thesis). Y1ldız Technical University Gradute School of Social Sciences, Istanbul, Turkey.

Özkaya, M. O., \& Erdem, S. (2009). Kadın girişimcilere yönelik strateji geliştirmede yerel yönetimlerle işbirliği içinde olmak, mümkün mü? Journal of Management and Economics Research, 11, 56-72.

Parvin, L., Rahman, M. W., \& Jia, J. (2012). Determinates of women micro-entrepreneurship development: an empirical investigation in rural Bangladesh. International Journal of Economics and Finance, 4(5), 254-260. 
http://dx.doi.org/10.5539/ijef.v4n5p254

Pelligrini, A. V. (2005). The impact of stereotype threat on intelligence testing in Hispanic females (Unpublished doctoral dissertation). Carlos Albizu University, San Juan, Puerto Rico. Available from ProQuest Dissertation \& Theses.

$\begin{array}{lllll}\text { ReducingStereotypeThreat. } & \text { (n.d.). } & \text { Retrieved } & \text { April } & 22, \quad 2016 \text {, from }\end{array}$ http://www.reducingstereotypethreat.org/definition.html

Rosenthal, C. (2006). Reducing stereotype threat by blurring intergroup boundaries. Personality and Social Psychology Bulletin, 32(4), 501-511. http://dx.doi.org/10.1177/0146167205281009

Serdaroğlu, U. (2010). İktisat ve Toplumsal Cinsiyet. Ankara, Turkey: Efil Yayınevi.

Sexton, D. L., \& Bowman-Upton, N. (1990). Female and male entrepreneurs: Psychological characteristics and their role in gender-related discrimination. Journal of Business Venturing, 5, 29-36.

Shinar, E. H. (1975). Sexual stereotypes of occupations. Journal of Vocational Behavior, 7, 99-111. http://dx.doi.org/10.1016/0001-8791(75)90037-8

Sijtsma, K. (2009). On the use, the misuse, and the very limited usefulness of Cronbach's alpha. Psychometrika, 74, 107-120. http://dx.doi.org/10.1007/s11336-008-9101-0

Simsek, M., \& Uzay, N. (2009). Economic and social problems of women entrepreneurs and Turkey application. Journal of Academic Research in Economics, 1(3), 289-307.

Soysal, A. (2010a). Characteristics of women entrepreneurs, problems they encountered and suggestions to women for establishing business: A research in Kahramanmaraş. Eskişehir Osmangazi Üniversitesi İ̈BF Dergisi, 5(1), 71-95.

Soysal, A. (2010b). Women entrepreneurs in Turkey: An assessment in the context of difficulties and opportunities. Ankara Üniversitesi SBF Dergisi, 65(1), 83-114.

Steele, C. M., \& Aronson, J. (1995). Stereotype threat and the intellectual test performance of African Americans. Journal of Personality and Social Psychology, 69(5), 797-811. http://dx.doi.org/10.1037/0022-3514.69.5.797

Takay, B. A., \& Tüzün, İ. K. (2015). What if women entrepreneurs become Schumpeterian entrepreneur. Niğde Üniversitesi ITBF Dergisi, 8(1), 249-259.

Ufuk, H., \& Özgen, Ö. (2001a). Interaction between the business and family lives of women entrepreneurs in Turkey. Journal of Business Ethics, 31, 95-106.

Ufuk, H., \& Özgen, Ö. (2001b). The profile of women entrepreneurs: A sample from Turkey. International Journal of Consumer Studies, 25 (4), 299-308.

Uluköy, M., \& Bayraktaroğlu, S. (2014). A field research about oppression incurred of woman entrepreneurs in patriarchal societies. Yönetim ve Ekonomi Araştırmaları Dergisi, 24, 356-369.

Uluköy, M., \& Demireli, C. (2014). Gender effect on entrepreneurship profile: A comparative analysis of male and female entrepreneurship. Yönetim ve Ekonomi Araştırmalarl Dergisi, 22, 47-55. http://dx.doi.org/10.11611/JMER245

Upadhye, J. (2012). Entrepreneurship Among Poverty-ridden Women: The Confidence Building Index. International Journal of Trade, Economics and Finance, 3(2), 132-135. http://dx.doi.org/10.7763/IJTEF.2012.V3.186

Vescio, T., \& Weaver, K. (2013). Prejudice and Stereotyping. Oxford Bibliographies. http://dx.doi.org/10.1093/obo/9780199828340-0097

Yalman, İ. N., \& Gündoğdu, Ö. (2014). The importance of women entrepreneurships in regional development: the application in TR72 (Kayseri, Sivas, Yozgat) region. Journal of Entrepreneurship and Development, 9(1), 39-70.

Yetim, N. (2008). Social capital in female entrepreneurship. International Sociology, 23(6), 864-885. http://dx.doi.org/10.1177/0268580908095913

Yirik, Ş., \& Yıldırım, B. I. (2014a). Analysis of personal values of women entrepreneurs of tourism sector in terms of their demographic characteristics: The case of Antalya. Mustafa Kemal University Journal of Graduate School of Social Sciences, 11(26), 361-378. 
Yirik, SS., \& Yıldırım, B.I. (2014b). Field study of relations between personal values of women entrepreneurs in tourism sector and their perception of risk and uncertainty perceptions: the case of Antalya. Nigde Üniversitesi ITBF Dergisi, 2014, Cilt: 7, Sayı: 2, s.97-111.

Zeyneloğlu, S., \& Terzioğlu, F. (2011). Development and psychometric properties gender roles attitude scale. Hacettepe University Journal of Education, 40, 409-420.

\section{Copyrights}

Copyright for this article is retained by the author(s), with first publication rights granted to the journal.

This is an open-access article distributed under the terms and conditions of the Creative Commons Attribution license (http://creativecommons.org/licenses/by/4.0/). 